\title{
The effect of ceria co-doping on chemical stability and fracture toughness of Y-TZP
}

\author{
M. M. R. BOUTZ*, A. J. A. WINNUBST, B. VAN LANGERAK, R. J. M. OLDE \\ SCHOLTENHUIS, K. KREUWEL, A. J. BURGGRAAF \\ University of Twente, Faculty of Chemical Technology, Laboratory for Inorganic Chemistry, \\ Materials Science and Catalysis, P.O. Box 217, 7500 AE Enschede, The Netherlands
}

\begin{abstract}
The fracture toughness and ageing resistance of yttria, ceria-stabilized tetragonal zirconia polycrystals ( $\mathrm{Y}, \mathrm{Ce}-\mathrm{TZP})$ were evaluated as a function of grain size and ceria content. Very fine grained, fully dense materials could be produced by sinter forging at relatively low temperatures $\left(1150-1200^{\circ} \mathrm{C}\right)$. The ageing resistance in hot water $\left(185^{\circ} \mathrm{C}\right)$ of $2 \mathrm{~mol} \% \mathrm{Y}_{2} \mathrm{O}_{3}$ stabilized TZP is strongly enhanced by alloying with ceria. The ceria content necessary to avoid degradation completely, decreases with grain size. The toughness of fully dense $Y$, $\mathrm{Ce}$-TZP is 7-9 MPa ${ }^{1 / 2}$ for grain sizes down to $0.2 \mu \mathrm{m}$. No or very little transformation took place during fracturing and no clear variation with grain size was observed for the toughness at grain sizes up to $0.8 \mu \mathrm{m}$. Reversible transformation and crack deflection may explain the observed toughness values.
\end{abstract}

\section{Introduction}

Y-TZP ceramics possess excellent strength, low grainboundary mobility and can be formed superplastically, but the stability of the tetragonal phase in moist air or hot water at $100-500^{\circ} \mathrm{C}$ is quite poor and only moderate values are found for the fracture toughness. Maximum values of $9-12 \mathrm{MPa} \mathrm{m}^{1 / 2}$ have been reported for the toughness $[1,2]$, but a more typical value is $8 \mathrm{MPam}^{1 / 2}$. Ce-TZP ceramics, on the other hand, display a considerably improved resistance against ageing [3] and a high fracture toughness [4], but the strength of these materials is generally low and superplastic forming is not possible owing to strong dynamic grain growth.

It is therefore anticipated that TZP ceramics with a good resistance against ageing, low grain-boundary mobility, good formability during hot-forging processes and excellent mechanical properties might be fabricated using both yttria and ceria as stabilizers for the tetragonal phase. It has been demonstrated [5] that, at temperatures starting from $1200^{\circ} \mathrm{C}$, grain growth in YCe-TZP is much slower than in Ce-TZP, but remains faster than in Y-TZP. Good formability has been found during sinter forging at $1100-1200^{\circ} \mathrm{C}$ under constant load, as has been described elsewhere [6]. Creep strains up to 0.8 at strain rates larger than $10^{-4} \mathrm{~s}^{-1}$ were observed, while the microstructure remained equiaxed and very limited dynamic grain growth occurred. These are properties typical of superplastic materials.

It should be recognized that the poor stability of the tetragonal phase in humid atmospheres at $100-500^{\circ} \mathrm{C}$ leads to a severe limitation of the possible applications of Y-TZP as a structural and wear-resistant material. The transformation of the tetragonal to the monoclinic phase during ageing proceeds from the surface to the interior and is accompanied by the formation of micro- and macro-cracks. This can ultimately lead to a drastic loss of strength or even a complete loss of structural integrity [7].

Several authors [8-13] have investigated this degradation phenomenon and tried to define the role of microstructural and environmental parameters. There is general agreement that degradation is strongly influenced by (a) the composition; i.e. the mole percentage yttria, (b) the grain size, (c) the temperature, and (d) the partial water vapour pressure. Degradation in moist air occurs at temperatures between 100 and $500^{\circ} \mathrm{C}$ and a broad maximum in the extent of transformation is observed at $200-300^{\circ} \mathrm{C}$. The upper temperature limit is thermodynamically defined and decreases with increasing yttria content and decreasing grain size, while the lower temperature limit is kinetically defined and is independent of grain size and composition $[10,12]$. The transformation is strongly accelerated by increasing the water vapour pressure and degradation is most severe under hydrothermal conditions, i.e. in water at elevated pressures above $100^{\circ} \mathrm{C}$. In hot water the extent of transformation has already reached a broad maximum at $100-200^{\circ} \mathrm{C}[11]$.

Below a critical grain size, $D_{c}$, the tetragonal phase is not susceptible to low-temperature degradation. The value of $D_{\mathrm{c}}$ depends on the mole percentage yttria and several authors [13-15] have tried to define a grain size versus composition stability field for ageing 
of Y-TZP: in moist air, $D_{\mathrm{c}}=0.2 \mu \mathrm{m}$ for $2 \mathrm{~mol} \%$ $\mathrm{Y}_{2} \mathrm{O}_{3}$, and for $3 \mathrm{~mol} \% \mathrm{Y}_{2} \mathrm{O}_{3}$, values of $0.3-0.4 \mu \mathrm{m}$ are reported $[14,15]$. The toughness of such fine-grained materials is, however, generally lower than that of their coarser-grained equivalents [16] and an increase in stability is thus obtained at the expense of a loss in toughness.

By co-doping Y-TZP with ceria a good stability of the $t$-phase can be obtained $[17,18]$, possibly without a loss in toughness. In the present work, the ageing resistance and toughness of YCe-TZP have been evaluated as a function of ceria content and grain size. Very fine-grained materials fabricated by free sintering or sinter forging at low temperatures $\left(1150 / 1200^{\circ} \mathrm{C}\right)$ were compared with their coarser-grained equivalents prepared by post-densification annealing treatments at more elevated temperatures.

\section{Experimental procedure}

Powders have been synthesized by a gel precipitation technique using metal chlorides as precursor chemicals. This synthesis method will be referred to as the chloride method and has been described in greater detail elsewhere [19]. The investigated compositions are listed in Table I. Green samples used for pressureless densification were prepared by cold isostatic compaction in two steps: first at $80-100 \mathrm{MPa}$ and finally at $400 \mathrm{MPa}$. Specimens for ageing tests were free sintered at $1150^{\circ} \mathrm{C}$ for $10 \mathrm{~h}$ or at $1400^{\circ} \mathrm{C}$ for $3 \mathrm{~h}$; heating and cooling rates were 120 and $240^{\circ} \mathrm{Ch}^{-1}$, respectively. To prevent cracking due to differential sintering, larger specimens intended for fracture toughness determination were first free sintered at $1050^{\circ} \mathrm{C}$ for $10 \mathrm{~h}$ (heating/cooling rate $60^{\circ} \mathrm{C} \mathrm{h}^{-1}$ ) and finally at $1150^{\circ} \mathrm{C}$ for $10 \mathrm{~h}$ (heating/cooling rate $60-120^{\circ} \mathrm{C} \mathrm{h}^{-1}$ ). Direct sintering at $1150^{\circ} \mathrm{C}$ often leads to severe cracking. To increase the grain size, annealing treatments were performed at $1400^{\circ} \mathrm{C}$ $(2-50 \mathrm{~h}), 1450$ and $1550^{\circ} \mathrm{C}(6 \mathrm{~h})$.

Rectangular specimens intended for sinter forging tests were made by cold uniaxial compaction at $50 \mathrm{MPa}$ in a steel die $(40 \mathrm{~mm} \times 8 \mathrm{~mm})$, followed by isostatic compaction at $400 \mathrm{MPa}$. Before sinter forging, the specimens were presintered by heating at $120^{\circ} \mathrm{Ch}^{-1}$ to $950^{\circ} \mathrm{C}$, immediately followed by cooling down. Prior to sinter forging, specimens were machined to their appropriate dimensions: length $\times$ height $\times$ width were $15 \mathrm{~mm} \times 6 \mathrm{~mm} \times 6 \mathrm{~mm}$ in the case of $\mathrm{ZY} 4 \mathrm{Ce} 2$ and $\mathrm{ZY} 4 \mathrm{Ce} 8$ or $15 \mathrm{~mm} \times 8 \mathrm{~mm} \times$ $6 \mathrm{~mm}$ in the case of ZY5. Sinter forging tests were performed in air at 1150 and $1200^{\circ} \mathrm{C}$ under constant

TABLE I. Composition of the investigated TZPS

\begin{tabular}{llll}
\hline Code & $\begin{array}{l}\mathrm{ZrO}_{2} \\
(\mathrm{~mol} \%)\end{array}$ & $\begin{array}{l}\mathrm{YO}_{1.5} \\
(\mathrm{~mol} \%)\end{array}$ & $\begin{array}{l}\mathrm{CeO}_{2} \\
(\mathrm{~mol} \%)\end{array}$ \\
\hline ZY5 & 95 & 5 & - \\
ZY4Ce2 & 94 & 4 & 2 \\
ZY4Ce4 & 92 & 4 & 4 \\
ZY4Ce6 & 90 & 4 & 6 \\
ZY4Ce8 & 88 & 4 & 8 \\
\hline
\end{tabular}

load using an Elatec hydraulic compression machine. Details of the experimental configuration of this machine have been given elsewhere [6]. Specimens were heated to $950{ }^{\circ} \mathrm{C}$ at $600^{\circ} \mathrm{C} \mathrm{h}^{-1}$, followed by heating at $300^{\circ} \mathrm{Ch}^{-1}$ to the end temperature. The load was raised to its final value in a linear fashion during heating from 950 to $1150 / 1200^{\circ} \mathrm{C}$ during most of the tests. Upon reaching the end temperature, the load was kept constant for $25 \mathrm{~min}$ at a value corresponding with an initial stress of $80 \mathrm{MPa}$ (calculated on the basis of the dimensions before testing). The load was imposed on the $15 \mathrm{~mm} \times 6 \mathrm{~mm}$ side of the specimens. At the end of the test the furnace power was switched off, resulting in a sudden temperature drop. The creep strain, $\varepsilon_{\mathrm{c}}$, was calculated from Equation 1, following the approach of Raj [20]

$\varepsilon_{\mathrm{c}}=\frac{2}{3}\left\{\frac{1}{2}\left[\left(\varepsilon_{x}-\varepsilon_{y}\right)^{2}+\left(\varepsilon_{y}-\varepsilon_{z}\right)^{2}+\left(\varepsilon_{z}-\varepsilon_{x}\right)^{2}\right]\right\}^{1 / 2}$

where $\varepsilon_{x}, \varepsilon_{y}$ and $\varepsilon_{z}$ are the true strains in the $x, y$ and $z$ directions.

Densities were measured by the Archimedes technique (in mercury). In some cases the density of $K_{\mathrm{Ic}}$ beams was calculated using their mass and geometrical dimensions. A Netzsch $402 \mathrm{E}$ dilatometer was used in limited cases to evaluate the sintering and high-temperature annealing behaviour of the investigated TZPs. Average grain sizes, $D$, were determined by the lineal intercept technique from scanning electron micrographs (Hitachi S800 or Jeol JSM-35CF) of polished, thermally etched cuts, using $D=1.56 \mathrm{~L}$, where $L$ is the average lineal intercept.

The stability of the t-phase was tested by ageing in hot water at $185^{\circ} \mathrm{C}$ for $4.5-66 \mathrm{~h}$ under a $75-80$ bar nitrogen pressure using a glass container and sample holder. To ensure that the stability of the bulk of the materials was tested, polished cuts of sintered samples were used. The fracture toughness, $K_{\mathrm{Ic}}$, has been measured in three-point bending using the SENB (single-edge notched beam) technique. A Nimonic bending fixture with a span width of $12 \mathrm{~mm}$ has been used. Specimen dimensions were $13 \mathrm{~mm} \times 3 \mathrm{~mm} \times$ $1 \mathrm{~mm}$, the length and width of the notch, inserted using a diamond saw, were 500 and $45 \mu \mathrm{m}$, respectively. After applying the notch, specimens were annealed at $1000^{\circ} \mathrm{C}$ to eliminate the transformation zone, if any. A crosshead displacement rate of $0.3 \mathrm{~mm} \mathrm{~min}{ }^{-1}$ was used during all tests. Specimens were not precracked. The hardness of the investigated TZPs was measured on polished, thermally annealed cuts by Vickers indentation using a load of $50 \mathrm{~kg}$.

Micro-Raman spectroscopy has been used in limited cases to inspect the phase content on fracture surfaces and near radial cracks emanating from the Vickers indents. Quantitative determination of the phase content on aged and fractured surfaces took place by XRD using a Philips PW1710 diffractometer. The equation proposed by Toraya et al. [21] was used to determine the volume fraction of monoclinic zirconia, $V_{\mathrm{m}}$. On aged surfaces, integral intensities of the diffraction peaks of interest were obtained by stepwise counting the intensity using a step size of $0.01^{\circ}(2 \theta)$ and a counting time of $3 \mathrm{~s}$. Intensities were corrected for the background. To determine integral 
intensities on fracture surfaces, step scans were taken over the $26^{\circ}-33^{\circ}(2 \theta)$ with a step size of $0.015^{\circ}(2 \theta)$. At each step the intensity was counted for $10 \mathrm{~s}$. Samples were pressed into a synthetic clay for X-ray diffraction (XRD) measurements. Diffraction peaks of the synthetic clay appeared in the measured $2 \theta$ range. A pattern-fitting technique has been used to separate the reflections of tetragonal and monoclinic zirconia from those of the clay material and to obtain integrated intensities (corrected for background).

Both at the aged and fracture surfaces a preferred orientation of the monoclinic phase was observed, because the observed intensity ratio of the $(-111)_{m}$ and $\left(\begin{array}{lll}1 & 1 & 1\end{array}\right)_{\mathrm{m}}$ diffraction peaks was always much larger than measured in a randomly oriented powder, where a ratio of 100:74 is invariably observed. The value of $V_{\mathrm{m}}$ calculated using the observed intensities of the monoclinic diffraction peaks in the aged and fractured samples (slightly) underestimates the true monoclinic volume content. A correction method has been proposed by Paterson and Stevens [22], from which corrections of $1 \%-5 \%$ are obtained at transformation levels of $10 \%-60 \%$. Such corrections are, however, within the experimental error of the $V_{\mathrm{m}}$ determination and no corrections have therefore been applied.

\section{Results}

\subsection{Ageing in hot water}

\subsubsection{Materials}

The relative densities and grain sizes of $\mathrm{ZY5}$ and ZY4Ce $x$ with $x=2-8$ after heat treatments at $1150^{\circ} \mathrm{C}$ $(10 \mathrm{~h})$ and $1400^{\circ} \mathrm{C}(3 \mathrm{~h})$ are given in Table II. All investigated TZPs could be sintered to $94 \%-97 \%$ relative density at $1150^{\circ} \mathrm{C}$, the observed grain sizes being equal to $0.2 \mu \mathrm{m}$ independent of composition. After the heat treatment at $1400^{\circ} \mathrm{C}(3 \mathrm{~h})$ final densities were $93 \%-96 \%$. During heating to this temperature all materials reach $95 \%-97 \%$ at $1250{ }^{\circ} \mathrm{C}$; a small loss of density is thus observed during annealing at $1400^{\circ} \mathrm{C}$. After annealing at $1400^{\circ} \mathrm{C}$, grain sizes of the $\mathrm{ZY} 4 \mathrm{Ce} x$ materials were $0.6 \mu \mathrm{m}$ independent of the ceria concentration, while the grain size of ZY5 remained equal to only $0.3 \mu \mathrm{m}$.

All materials were $100 \%$ tetragonal after sintering at $1150^{\circ} \mathrm{C}$ or annealing at $1400^{\circ} \mathrm{C}$.

\subsubsection{Ageing tests}

The monoclinic volume content of the investigated TZPs after ageing at $185^{\circ} \mathrm{C}$ in water for $4.5-66 \mathrm{~h}$ is given in Table III. The values of $V_{\mathrm{m}}$ are plotted versus the composition in Fig. 1, in which the compositions are denoted as ZY4(S), where $S$ can equal $1 Y$ or $x \mathrm{Ce}$ with $x=2-8$. Grain sizes are given in Table II. It is clear from Tables II and III and Fig. 1 that the ageing resistance strongly depends on both grain size and composition. The stability of the t-phase increases with decreasing grain size and increasing ceria content. The differences in $V_{\mathrm{m}}$ between ageing times of 4.5 or $66 \mathrm{~h}$ are negligible.

During ageing of $\mathrm{ZY} 5$ and $\mathrm{ZY} 4 \mathrm{Ce} 2$, sintered at $1400^{\circ} \mathrm{C}$, an almost complete transformation to the
TABLE II Grain sizes and relative densities of the investigated TZPs after free sintering at $1150^{\circ} \mathrm{C}(10 \mathrm{~h})$ or at $1400^{\circ} \mathrm{C}(3 \mathrm{~h})$

\begin{tabular}{|c|c|c|c|c|}
\hline \multirow[t]{2}{*}{ Composition } & \multicolumn{2}{|c|}{$1150^{\circ} \mathrm{C}, 10 \mathrm{~h}$} & \multicolumn{2}{|c|}{$1400^{\circ} \mathrm{C}, 3 \mathrm{~h}$} \\
\hline & $\begin{array}{l}D \\
(\mu \mathrm{m})\end{array}$ & $\begin{array}{l}\rho_{\text {rel }} \\
(\%)\end{array}$ & $\begin{array}{l}D \\
(\mu \mathrm{m})\end{array}$ & $\begin{array}{l}\rho_{\text {rel }} \\
(\%)\end{array}$ \\
\hline ZY5 & 0.20 & 97 & 0.30 & 95 \\
\hline $\mathrm{ZY} 4 \mathrm{Ce} 2$ & 0.21 & 96 & 0.62 & 93 \\
\hline ZY4Ce4 & 0.21 & 95 & 0.62 & 96 \\
\hline ZY4Ce6 & 0.21 & 96 & 0.61 & 92 \\
\hline ZY4Ce8 & 0.22 & 94 & 0.66 & 96 \\
\hline
\end{tabular}

TABLE III Monoclinic volume content, $V_{m}$, after ageing at $185^{\circ} \mathrm{C}$ in water for $4.5,41$ and $66 \mathrm{~h}$

\begin{tabular}{llrrr}
\hline \multirow{2}{*}{ Composition } & Sintering & \multicolumn{2}{l}{$V_{\mathrm{m}}(\%)$} & \\
\cline { 3 - 5 } & $\begin{array}{l}\text { temperature } \\
\left({ }^{\circ} \mathrm{C}\right)\end{array}$ & $4.5 \mathrm{~h}$ & $41 \mathrm{~h}$ & $66 \mathrm{~h}$ \\
\hline ZY5 & 1150 & 41 & 44 & 47 \\
ZY4Ce2 & 1150 & 53 & 35 & 50 \\
ZY4Ce4 & 1150 & 0 & 0 & 1 \\
ZY4Ce6 & 1150 & 0 & 0 & 0 \\
ZY4Ce8 & 1150 & 0 & 0 & 0 \\
ZY5 & 1400 & 88 & 89 & 91 \\
ZY4Ce2 & 1400 & 100 & 100 & 100 \\
ZY4Ce4 & 1400 & 24 & 22 & 24 \\
ZY4Ce6 & 1400 & 0 & 0 & 2 \\
ZY4Ce8 & 1400 & 0 & 0 & 0 \\
\hline
\end{tabular}

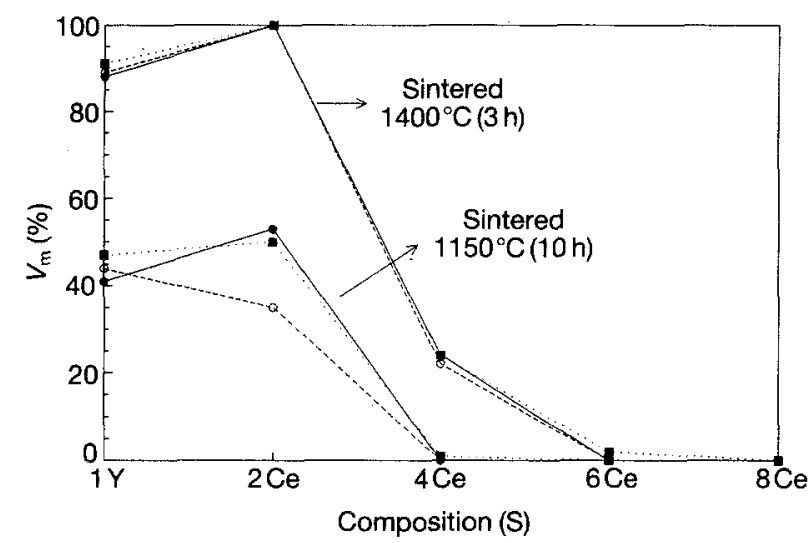

Figure 1 The monoclinic volume content, $V_{\mathrm{m}}$, as a function of the composition of the investigated TZPs after ageing in water at $185^{\circ} \mathrm{C}$ for (- $4.5,(--) 41$ and $(\cdots) 66 \mathrm{~h}$. The investigated compositions are represented by $\mathrm{S}$, as in $\mathrm{ZY} 4(\mathrm{~S})$, where $\mathrm{S}$ is $1 \mathrm{Y}, 2 \mathrm{Ce}, 4 \mathrm{Ce}, 6 \mathrm{Ce}$ or $8 \mathrm{Ce}$. After sintering at $1150^{\circ} \mathrm{C}$ the grain size equals $0.2 \mu \mathrm{m}$ independent of $\mathrm{S}$, while after sintering at $1400^{\circ} \mathrm{C}$ the grain size equals $0.3 \mu \mathrm{m}$ for $1 \mathrm{Y}$ and $0.6 \mu \mathrm{m}$ for all other compositions.

monoclinic phase took place. Severe cracking was observed in ZY5, while the ZY4Ce2 specimen disintegrated into a powder. All specimens, sintered at $1150^{\circ} \mathrm{C}$, retained their structural integrity during ageing. It can be seen from Fig. 1 and Table II that even at a grain size of $0.2 \mu \mathrm{m}$ the t-phase in ZY5 and $\mathrm{ZY} 4 \mathrm{Ce} 2$ is not completely stable, although the extent of transformation is much less than at a grain size of $0.6 \mu \mathrm{m}$ (sintered at $1400^{\circ} \mathrm{C}$ ). At a grain size of $0.2 \mu \mathrm{m}$, 
4 at $\%$ cerium is required to stabilize fully the tetragonal phase during hydrothermal ageing in ZY4Cex, while at $0.6 \mu \mathrm{m}, 6$ at $\%$ cerium is required.

\subsection{Toughness of free sintered, sinter forged and aged $\mathrm{YCe}-\mathrm{TZP}$}

\subsubsection{Free sintered materials}

As mentioned in Section 3.1.1, all investigated TZPs can be sintered to densities $\geqslant 95 \%$ at $1150^{\circ} \mathrm{C}$. A very fine grain size of $0.2 \mu \mathrm{m}$ is observed after this sintering schedule, independent of composition. The toughness of TZP generally increases with increasing grain size until spontaneous transformation to the monoclinic phase occurs, because grain coarsening leads to an increased transformability of the t-phase under an applied stress field and is hence expected to lead to an enhanced shielding of the crack tip [16]. Therefore, the grain size of all TZP materials was increased after sintering at $1150^{\circ} \mathrm{C}$ by pressureless heat treatments at $1400^{\circ} \mathrm{C}$.

The fracture toughness together with grain sizes and relative densities of YCe-TZP are given in Table IV. The monoclinic volume content as measured by XRD on the fracture surface are also given in this table. The toughness of ZY5 at three different grain sizes has previously been measured by Theunissen et al. [23] and their values are also shown in Table IV. All grain sizes are within the range $0.2-0.8 \mu \mathrm{m}$. The variation of toughness with grain size is illustrated in Fig. 2 for all investigated TZPs. The measured toughness values of YCe-TZP are all within the range 5-7 MPa ${ }^{1 / 2}$ and there is no clear variation with grain size or composition. The toughness values of ZY5 are slightly higher than those of YCe-TZP, the measured values being equal to 7-8 $\mathrm{MPa} \mathrm{m}^{1 / 2}$. It can be seen in Table IV that only in limited cases some (irreversible) transformation to the monoclinic phase took place during fracturing. Again, no clear variation of the toughness

TA B LE IV Fracture toughness, $K_{\mathrm{Ic}}$, grain size $D$, relative density, $\rho_{\mathrm{rel}}$, and monoclinic volume content on the fracture surface, $V_{\mathrm{f}}$, of the investigated TZPs after various pressureless heat treatments

\begin{tabular}{|c|c|c|c|c|c|}
\hline Composition & $\begin{array}{l}\text { Final heat } \\
\text { treatment }^{\mathrm{a}}\end{array}$ & $\begin{array}{l}D \\
(\mu \mathrm{m})\end{array}$ & $\begin{array}{l}\rho_{\text {rel }} \\
(\%)\end{array}$ & $\begin{array}{l}V_{\mathrm{f}} \\
(\%)\end{array}$ & $\begin{array}{l}K_{\mathrm{Ic}} \\
\left(\mathrm{MPa} \mathrm{m}^{1 / 2}\right)\end{array}$ \\
\hline ZY5 [23] & $\begin{array}{l}\mathrm{A} \\
\mathrm{B} 1 \\
\mathrm{C}\end{array}$ & $\begin{array}{l}0.18 \\
0.30 \\
0.75\end{array}$ & $\begin{array}{l}97 \\
99 \\
98\end{array}$ & $\begin{array}{r}0 \\
0 \\
45\end{array}$ & $\begin{array}{l}7.3 \pm 0.5 \\
8.4 \pm 0.8 \\
8.3 \pm 0.5\end{array}$ \\
\hline ZY4Ce2 & $\begin{array}{l}\text { B1 } \\
\text { B2 } \\
\text { B3 }\end{array}$ & $\begin{array}{l}0.60 \\
0.71 \\
0.74\end{array}$ & $\begin{array}{l}96 \\
96 \\
98\end{array}$ & $\begin{array}{r}0 \\
36 \\
37\end{array}$ & $\begin{array}{l}6.1 \pm 0.5 \\
6.4 \pm 0.4 \\
6.6 \pm 0.6\end{array}$ \\
\hline ZY4Ce4 & $\begin{array}{l}\text { A } \\
\text { B1 } \\
\text { B3 }\end{array}$ & $\begin{array}{l}0.21 \\
0.50 \\
0.76\end{array}$ & $\begin{array}{l}95 \\
99 \\
99\end{array}$ & $\begin{array}{r}0 \\
0 \\
12\end{array}$ & $\begin{array}{l}5.0 \pm 0.6 \\
7.1 \pm 1.1 \\
6.1 \pm 1.1\end{array}$ \\
\hline ZY4Ce6 & $\begin{array}{l}\text { B1 } \\
\text { B2 } \\
\text { B3 }\end{array}$ & $\begin{array}{l}0.62 \\
0.68 \\
0.76\end{array}$ & $\begin{array}{l}97 \\
97 \\
99\end{array}$ & $\begin{array}{l}0 \\
0 \\
0\end{array}$ & $\begin{array}{l}5.7 \pm 0.7 \\
5.3 \pm 0.5 \\
6.2 \pm 0.7\end{array}$ \\
\hline ZY4Ce8 & $\begin{array}{l}\text { B1 } \\
\text { B2 } \\
\text { B3 }\end{array}$ & $\begin{array}{l}0.54 \\
0.67 \\
0.76\end{array}$ & $\begin{array}{l}98 \\
96 \\
98\end{array}$ & $\begin{array}{r}24 \\
0 \\
0\end{array}$ & $\begin{array}{l}6.9 \pm 0.5 \\
5.4 \pm 0.7 \\
5.6 \pm 0.3\end{array}$ \\
\hline
\end{tabular}

${ }^{\mathrm{a}} \mathrm{A}, 1150^{\circ} \mathrm{C}, 10 \mathrm{~h} ; \mathrm{B} 1,1400^{\circ} \mathrm{C}, 2 \mathrm{~h} ; \mathrm{B} 2,1400^{\circ} \mathrm{C}, 12 \mathrm{~h} ; \mathrm{B} 3,1400^{\circ} \mathrm{C}$, $50 \mathrm{~h} ; \mathrm{C}, 1600^{\circ} \mathrm{C}, 2 \mathrm{~h}$.

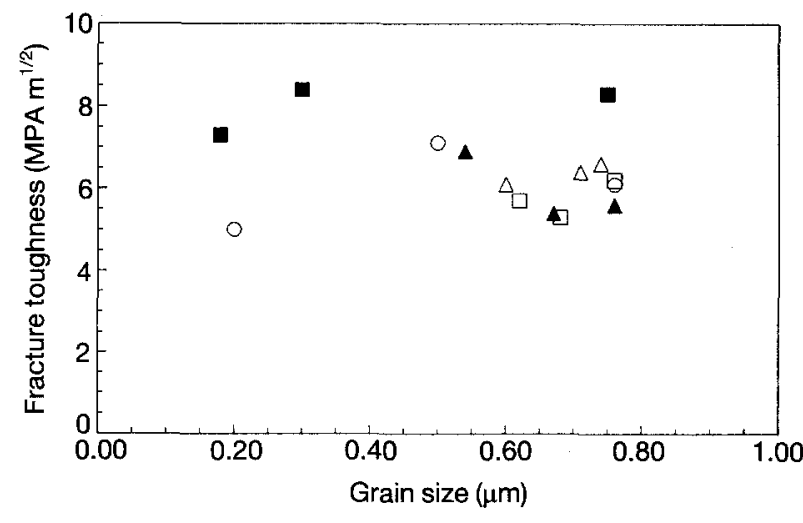

Figure 2 The fracture toughness, measured by the SENB technique, of the investigated TZPs as a function of grain size. Compositions are labelled in the legend as in Fig. 1.(口) $1 \mathrm{Y},(\triangle) 2 \mathrm{Ce},(\bigcirc) 4 \mathrm{Ce},(\square)$ $6 \mathrm{Ce},(\Delta) 8 \mathrm{Ce}$.

with the extent of transformation is observed. For all investigated TZPs the toughness seems not to be determined by a stress induced irreversible transformation to the monoclinic phase, as will be further discussed in Section 4.

The hardness of YCe-TZP heat treated at $1400^{\circ} \mathrm{C}$ for 12-62 $\mathrm{h}$ as measured by Vickers indentation using a load of $50 \mathrm{~kg}$ was equal to $10-12 \mathrm{GPa}$, independent of composition and grain size $(0.7-0.8 \mu \mathrm{m})$. These hardness values are similar to those of Ce-TZP [24] and Y-TZP [25] $(D=0.4-0.5 \mu \mathrm{m})$. Micro-Raman spectroscopy has been used to examine transformation zones, which could have developed along radial cracks emanating from the indents. However, only Raman lines typical of the tetragonal phase could be detected near these cracks. The detection limit of the micro-Raman measurements was lower than the one of XRD and is estimated to be $20-30 \mathrm{vol} \%$ of the monoclinic phase. Nomarski interference microscopy showed no surface uplift around indents and their radial cracks, also indicating the absence of any transformation zone. Transformation zones always lead to a surface uplift [26] due to the volume expansion during the $\mathrm{t} \rightarrow \mathrm{m}$ transformation.

\subsubsection{Sinter forged materials}

Differential sintering led to the opening of macrocracks in several cases during free sintering of $\mathrm{YCe}-$ TZP. The formation of such cracks can be suppressed and the elimination of processing flaws enhanced by using sinter forging as a pressure-assisted densification technique. During sinter forging, a uniaxial load is applied to the specimens during densification and the specimens are allowed to move freely into the lateral direction. Large creep strains can be imposed on the densifying material [27]. A significant improvement of the mechanical properties is anticipated for sinter forged materials compared to their free sintered equivalents.

Here, it will be examined if the toughness of TZP can be improved by using sinter forging. After the forging process, grain coarsening was performed by pressureless annealing at $1400^{\circ} \mathrm{C}$ for $2 \mathrm{~h}$ in the case of YCe-TZP. During sinter forging, rectangular speci- 
TA BLE V Fracture toughness, $K_{\mathrm{Ic}}$, creep strain, $\varepsilon_{\mathrm{c}}$, final density, $\rho_{\mathrm{fin}}$, and grain size, $D$, of ZY5 and ZY4Ce2 sinter forged at 1150 or $1200^{\circ} \mathrm{C}$ eventually followed by pressureless annealing at $1400^{\circ} \mathrm{C}$

\begin{tabular}{|c|c|c|c|c|c|c|}
\hline Composition & $\begin{array}{l}\text { Sinter forging } \\
\text { temperature } \\
\left({ }^{\circ} \mathrm{C}\right)\end{array}$ & $\varepsilon_{\mathrm{c}}$ & $\begin{array}{l}\text { Annealing }^{\mathrm{b}} \\
\text { temperature } \\
\left({ }^{\circ} \mathrm{C}\right)\end{array}$ & $\begin{array}{l}D \\
(\mu \mathrm{m})\end{array}$ & $\begin{array}{l}\rho_{\text {fin }} \\
(\%)\end{array}$ & $\begin{array}{l}K_{\mathrm{Ic}} \\
\left(\mathrm{MPa} \mathrm{m}^{1 / 2}\right)\end{array}$ \\
\hline \multirow[t]{2}{*}{ ZY5 } & $1150^{\mathrm{c}}$ & 0.57 & - & 0.17 & 98 & $7.9 \pm 0.9$ \\
\hline & 1150 & 0.71 & - & 0.18 & $97^{\prime}$ & $8.8 \pm 0.9$ \\
\hline \multirow[t]{4}{*}{$\mathrm{ZY} 4 \mathrm{Ce} 2$} & $1150^{\mathrm{c}}$ & 0.49 & 1400 & 0.6 & 96 & $6.1 \pm 0.3$ \\
\hline & 1150 & 0.62 & 1400 & 0.6 & 91 & $5.2 \pm 0.4$ \\
\hline & 1200 & 0.84 & 1400 & 0.6 & 92 & $5.6 \pm 0.7$ \\
\hline & 1200 & 0.83 & - & 0.25 & 99 & $8.1 \pm 0.8$ \\
\hline
\end{tabular}

${ }^{a}$ Sinter forged for $25 \mathrm{~min}$ at the end temperature under an initial stress of $80 \mathrm{MPa}$. The load was raised to its final value during heating from $950^{\circ} \mathrm{C}$ to the end temperature.

${ }^{b}$ Dwell time $2 \mathrm{~h}$, heating/cooling rate $120^{\circ} \mathrm{C} \mathrm{h}^{-1}$.

${ }^{c}$ As ${ }^{(a)}$, but now the load was raised to its final value in 5 min upon reaching the end temperature.

mens were forged into a plate-like shape in air at 1150 or $1200^{\circ} \mathrm{C}$ under an initial stress of $80 \mathrm{MPa}$. Fracture toughness values, grain sizes, creep strains and final densities of ZY5 and ZY4Ce2 after sinter forging or sinter forging followed by pressureless annealing at $1400^{\circ} \mathrm{C}$ are listed in Table $\mathrm{V}$.

At $1150^{\circ} \mathrm{C}$ both investigated TZPs are sinter forged to a density of $96 \%-98 \%$ and creep strains are $0.5-0.7$, at $1200^{\circ} \mathrm{C}$ the final density and creep strain of $\mathrm{ZY} 4 \mathrm{Ce} 2$ are $98 \%-99 \%$ and 0.8 , respectively. Large creep strains are thus reached with near-theoretical densities during sinter forging. After sinter forging, $\mathrm{ZY} 4 \mathrm{Ce} 2$ specimens were annealed at $1400^{\circ} \mathrm{C}$, which led to a decrease of density, even down to $91 \%$ in one case. Without annealing the fracture toughness of the sinter forged TZPs was quite high: values of 8-9 $\mathrm{MPa} \mathrm{m}^{1 / 2}$ were measured for ZY5 sinter forged at $1150^{\circ} \mathrm{C}(D=0.18 \mu \mathrm{m})$, while a value of $8 \mathrm{MPa} \mathrm{m}^{1 / 2}$ was measured for $\mathrm{ZY} 4 \mathrm{Ce} 2$ sinter forged at $1200^{\circ} \mathrm{C}$ $(D=0.25 \mu \mathrm{m})$. XRD measurements of the fracture surface of the sinter forged TZPs showed that no transformation to the monoclinic phase took place during fracturing. After annealing at $1400^{\circ} \mathrm{C}$ the fracture toughness of $\mathrm{ZY} 4 \mathrm{Ce} 2$ decreased to 5-6 $\mathrm{MPa} \mathrm{m}^{1 / 2}$.

\subsubsection{Aged YCe-TZP}

The effect of ageing on the toughness of YCe-TZP has only been examined briefly. After sintering at $1400^{\circ} \mathrm{C}$ for $2 \mathrm{~h}\left(\rho_{\text {fin }}=99 \%\right) K_{\text {Ic }}$ beams were machined for the $\mathrm{ZY} 4 \mathrm{Ce} 4$ material. After applying the notch, the beams were annealed at $1000^{\circ} \mathrm{C}$ to remove the transformation zone (if present). Finally, these beams were aged at $185^{\circ} \mathrm{C}$ for $66 \mathrm{~h}$ in water. Before ageing these specimens were $100 \%$ tetragonal and the fracture toughness was equal to $7.1 \pm 1.1 \mathrm{MPa} \mathrm{m}^{1 / 2}$ $(D=0.50 \mu \mathrm{m}$, see Table IV). After ageing the monoclinic volume content at the surface was $10 \%-30 \%$ and the fracture toughness increased slightly to 8.1 $\pm 0.8 \mathrm{MPa} \mathrm{m}^{1 / 2}$.

\section{Discussion}

\subsection{Ageing of tetragonal zirconia}

In Section 3.1 it was demonstrated that the t-phase in ZY5 is quite unstable at $185^{\circ} \mathrm{C}$ in water, even at very fine grain sizes of $0.2-0.3 \mu \mathrm{m}$. Almost complete transformation to the monoclinic phase, accompanied by severe crack formation, takes place at $0.3 \mu \mathrm{m}$. At $0.2 \mu \mathrm{m}$, still $50 \%$ of the $\mathrm{t}$-phase transforms during ageing. These observations are in agreement with the stability field draft for Y-TZP in hot water given by Winnubst and Burggraaf [13]. The critical grain size below which no transformation should take place for ZY5 is near $0.1 \mu \mathrm{m}$ according to these authors. The effect of alloying Y-TZP with $\mathrm{CeO}_{2}$ on its ageing resistance has been investigated by adding $2-8 \mathrm{~mol} \%$ $\mathrm{CeO}_{2}$ to $\mathrm{ZY} 4$. The stability has been investigated at 0.2 and $0.6 \mu \mathrm{m}$. The ageing resistance of $\mathrm{ZY} 4$ in hot water $\left(180^{\circ} \mathrm{C}\right)$ has previously been investigated by Winnubst and Burggraaf [13]: they observed that even at $0.1 \mu \mathrm{m}$ an almost complete transformation took place during ageing. The beneficial effect of alloying $\mathrm{ZY} 4$ with $\mathrm{CeO}_{2}$ is clearly illustrated in Fig. 1, the concentration of $\mathrm{CeO}_{2}$ necessary to avoid transformation completely, being dependent on the grain size.

Other investigators have also observed this enhanced ageing resistance of YCe-TZP at grain sizes above $\sim 0.5 \mu \mathrm{m}$ : Sato et al. [17] alloyed $3 \mathrm{~mol} \%$ $\mathrm{Y}_{2} \mathrm{O}_{3}$-stabilized TZP (3Y-TZP) with 2-10 mol \% $\mathrm{CeO}_{2}$ and observed an increase of the critical grain size with increasing ceria content for ageing in hot water at $100^{\circ} \mathrm{C}$, Hernandez et al. [18] alloyed 2Y-TZP with $2-10 \mathrm{~mol} \%$ ceria and observed no ageing in hot water at $170^{\circ} \mathrm{C}$ if the ceria content was $6 \mathrm{~mol} \%$. The latter authors did not report grain sizes, but their materials were sintered at $1350{ }^{\circ} \mathrm{C}$ for $2 \mathrm{~h}$ and the grain size is estimated to be $0.5 \mu \mathrm{m}$. The results of Hernandez et al. are in good agreement with ours.

The mechanistic explanation of low-temperature ageing of tetragonal zirconia is still a matter of vigorous debate. Three main hypotheses have been put forward to explain this phenomenon. Sato and Shimada [9] proposed that the transformation is controlled by the breaking of $\mathrm{Zr}-\mathrm{O}-\mathrm{Zr}$ bonds during reaction with water; this would then lead to a relief of the constraint acting on the tetragonal grains and consequently to a transformation to the stable monoclinic phase. Lange et al. [28] observed the formation of $\mathrm{Y}(\mathrm{OH})_{3}$ by TEM in aged $\mathrm{Y}-\mathrm{TZP}$ and attributed the destabilization of the $t$-phase to the decrease in yttria 
content of the tetragonal grains due to the formation of this yttrium hydroxide. According to these authors, the critical grain size for ageing should coincide with the critical grain size for microcracking, the formation of microcracks leading to the exposure of subsurface grains to water and thus only requiring short-range yttrium diffusion during ageing. Yoshimura [29] suggested that strain accumulation due to diffusion of $\mathrm{OH}^{-}$by formation of $\mathrm{Zr}-\mathrm{OH}$ and $\mathrm{Y}-\mathrm{OH}$ bonds and leading to an expansion of the lattice, causes the nucleation of the monoclinic phase.

The formation of metal-OH bonds has clearly been observed with infrared spectroscopy [29] and X-ray photoelectron spectroscopy (XPS) measurements showed that it is yttrium rather than zirconium, which binds to the hydroxy groups. Recently, Kontouros et al. [30] observed, by elastic recoil detection (ERD), that hydrogen penetrates deep into $3 \mathrm{Y}-\mathrm{TZP}$ during ageing, while no such penetration was observed for 3Y-TZP alloyed with $\mathrm{TiO}_{2}$, which is not susceptible to degradation [31]. Formation of $\mathrm{Y}-\mathrm{OH}$ bonds and diffusion of $\mathrm{OH}^{-}$into the degrading material is thus experimentally confirmed. However, until now it has remains unclear if yttrium leaching by the formation of yttrium(oxy)hydroxides occurs to such an extent that this should destabilize the tetragonal phase.

Other factors, most noticeably residual stresses [32], are certainly playing an important role during ageing. These residual stresses result from the large thermal expansion anisotropy of tetragonal zirconia $[33,34]$. During cooling from the processing temperature, tensile stresses develop due to thermal expansion mismatch and this promotes the transformability of the t-phase especially at grain corners due to stress concentration [35]. The magnitude of these residual stresses is proportional to the ratio of the thermal expansion coefficients along the crystallographic $c$ - and $a$-axis $\left(\alpha_{c} / \alpha_{a}\right)$, which, in turn, scales with the tetragonality $(c / a)$ of the material [30]. These residual stresses can be relaxed by creep of the material. Creep of tetragonal zirconia ceramics is enhanced by decreasing grain size and increasing impurity content [36]. Relaxation of residual stresses will thus be stronger with decreasing grain size and increasing impurity content and this leads to a decrease of the transformability of the t-phase. This should hold both for transformation under an applied stress field and during low-temperature ageing. A decrease of the transformability during fracturing and ageing of $\mathrm{Y}$ TZP by increasing the impurity content $\left(\mathrm{Al}_{2} \mathrm{O}_{3}, \mathrm{SiO}_{2}\right)$ has indeed been observed by Mecartney [37]. Hughes et al. [38] also observed that the rate and extent of transformation during ageing are less for the more impure material. The increased ageing resistance of $\mathrm{Y}$ TZP by increasing the impurity content is thus explained by enhanced relaxation of residual stresses resulting from the thermal expansion mismatch. This relation between enhanced stress relaxation caused by impurities and improved ageing resistance has so far not been well recognized in the literature, to the best of our knowledge.

The increased ageing resistance of Y-TZP by alloying with $\mathrm{CeO}_{2}$ should be explainable in terms of the parameters and processes described above. The tetragonality of ZY4Cex varies only very little with the ceria concentration: at $x=0, c / a=1.0163$, while for $x$ $=10, c / a$ decreases to 1.0146 [23]. The magnitude of the residual stresses should, therefore, be virtually independent of the ceria content. Hernandez et al. [18] observed by XPS that no $\mathrm{Y}-\mathrm{OH}$ bonds are formed in YCe-TZP during ageing, and that cerium is enriched by a factor of 3 at the external surface of the aged specimens. The segregation layer of cerium thus seems to act as a protective coating for the yttrium sites and prevents degradation (indicating Lange's hypothesis holds, see above).

Hernandez et al. [18] did not analyse the composition of the surface before ageing and they speculated that the cerium enrichment took place during the sintering stage. XPS measurements of segregation in YCe-TZP at $1000-1400^{\circ} \mathrm{C}$ to the external surface $[39,40]$ or the grain boundaries [5] showed, however, that no such segregation of cerium occurs during sintering. Therefore, the segregation of cerium to the external surface as observed by Hernandez et al. must have taken place during ageing.

A detailed analysis of the processes occurring during ageing of $\mathrm{CeO}_{2}$-doped Y-TZP by electron microscopy and surface analysis techniques such as $\mathrm{X}$-ray photoelectron spectroscopy is thus needed to gain a better insight of the automatic processes leading to the improved ageing resistance of this material.

\subsection{Toughness of $\mathrm{Y}, \mathrm{Ce}-\mathrm{TZP}$}

In Section 3.2 it was shown that the fracture toughness of YCe-TZP as determined by SENB is always within the range 5-7 $\mathrm{MPa} \mathrm{m}^{1 / 2}$, except for sinter forged specimens, which were not pressureless annealed (at $1400^{\circ} \mathrm{C}$ ) afterwards. The variation of $K_{\mathrm{Ic}}$ can be explained on the basis of variations in density only. Residual porosities of $1 \%-9 \%$ are observed in the $K_{\mathrm{Ic}}$-specimens. Elementary fracture mechanics show that the fracture toughness for plane stress conditions is given by

$$
K_{\mathrm{Ic}}=(2 \gamma E)^{1 / 2}
$$

where $\gamma$ is the fracture energy and $E$ the elastic modulus. Both the fracture energy and the elastic modulus are a function of the residual porosity, $P$. The dependence of $\gamma$ on the residual porosity is given by [41]

$$
\gamma=\gamma_{0} \exp (-b P)
$$

where $\gamma_{0}$ is the fracture energy of the fully dense material and $b$ is a numerical constant, which can take a value between 2 and 5 depending on the pore morphology. Winnubst et al. [42] measured the variation of $E$ with residual porosity for cubic $\mathrm{ZrO}_{2}-\mathrm{Y}_{2} \mathrm{O}_{3}$ and found that the experimental data were well described by

$$
E=E_{0} \exp (-a P) \quad \text { for } \quad a=2.7
$$

where $E_{0}$ is the elastic modulus for zero porosity. Combining Equations 2-4 yields the dependence of 
$K_{\text {Ic }}$ on the porosity

$$
\begin{aligned}
K_{\mathrm{Ic}} & =\left\{2 \gamma_{0} E_{0} \exp [-(a+b) P]\right\}^{1 / 2} \\
& =\mathrm{K}_{\mathrm{Ic}}^{0} \exp \left[-\frac{1}{2}(a+b) P\right]
\end{aligned}
$$

where $K_{\mathrm{Ic}}^{0}$ is the toughness of the fully dense material. Equation 5 can be conveniently rearranged to

$$
\ln \left(K_{\mathrm{Ic}}\right)=\ln \left(K_{\mathrm{Ic}}^{0}\right)-\frac{1}{2}(a+b) P
$$

If the fracture energy, $\gamma_{0}$, is constant, Equation 6 shows that plotting $\ln \left(K_{\text {Ic }}\right)$ versus $P$ should yield a straight line with a slope equal to $-\frac{1}{2}(a+b)$. Fig. 3 shows such a plot for $\mathrm{ZY} 4 \mathrm{Ce} 2$ with residual porosities of $1 \%-9 \%$. Indeed, a linear dependence of $\log \left(K_{\text {Ic }}\right)$ with $P$ is observed. From the slope of the curve and $a=2.7$ (see above) it can be calculated that $b$ equals 3.4. From Fig. 3 it can be determined that the fracture toughness for zero porosity equals $7 \mathrm{MPa} \mathrm{m}^{1 / 2}$. This value is in good agreement with the experimentally observed value of $7.1 \pm 1.1 \mathrm{MPa} \mathrm{m}^{1 / 2}$ of $\mathrm{ZY} 4 \mathrm{Ce} 4$ with a residual porosity less than $1 \%$. A value of $130 \mathrm{~J} \mathrm{~m}^{-2}$ for the fracture energy has been calculated for this material assuming $E_{0}=210 \mathrm{GPa}$ [43]. The slightly higher toughness values observed for Y-TZP in comparison with YCe-TZP (see Fig. 2) can be explained on the basis of Equation 5 if the product $\gamma_{0} E_{0}$ is larger for Y-TZP.

Great care has to be taken in order to make a comparison with literature data of the toughness of Y-TZP, Ce-TZP and YCe-TZP. Firstly, many researchers use micro-indentation to measure $K_{\mathrm{Ic}}$, because this technique is not time- and material-consuming. But, for tough materials such as TZP, small crack length/indent size ratios are observed and the obtained values often overestimate the true toughness of these materials. Techniques such as double cantilever beam (DCB) and SENB can give reliable values of the toughness only if the transformation zone around the crack/notch is removed by annealing at elevated temperatures prior to fracturing. If no annealing step has been performed, the SENB toughness becomes dependent on the notch width, as has been demonstrated by Wang et al. [2]. For instance, these authors found that the true toughness of $2 \mathrm{Y}-\mathrm{TZP}$ equals

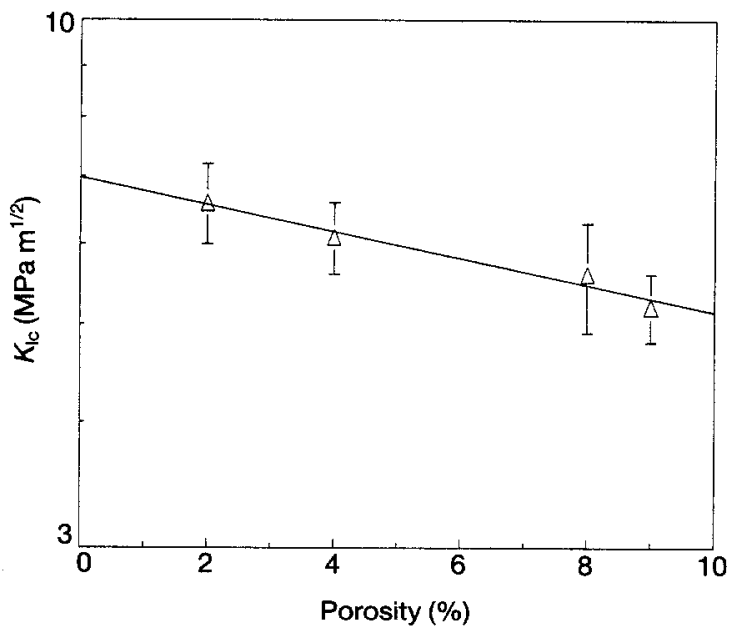

Figure 3 Variation of the fracture toughness, $K_{\mathrm{lc}}$, of $\mathrm{ZY} 4 \mathrm{Ce} 2$ with the residual porosity. Note that $K_{\mathrm{Ic}}$ is plotted on a logarithmic scale. All materials were annealed at $1400^{\circ} \mathrm{C}$ for $2-50 \mathrm{~h}$.
$12 \mathrm{MPam}^{1 / 2}$, but not removing the transformation zone around the notch increased the apparent toughness to $17-20 \mathrm{MPam}^{1 / 2}$ at notch widths of $150-700 \mu \mathrm{m}$. They also found that the true toughness of Y-TZP stabilized with $2.5-3 \mathrm{~mol} \% \quad \mathrm{Y}_{2} \mathrm{O}_{3}$ is $8-8.5 \mathrm{MPa} \mathrm{m}^{1 / 2}$ (grain size $\sim 1 \mu \mathrm{m}$ ). The optimum fracture toughness of $12 \mathrm{Ce}-\mathrm{TZP}$ equals $14 \mathrm{MPa} \mathrm{m}^{1 / 2}$ as observed by Wang et al. [4] using the SENB technique.

The toughness of YCe-TZP has so far only been measured by indentation techniques. Duh and Wan [44] observed toughness values of 10-22 $\mathrm{MPam}^{1 / 2}$ depending on the composition for ZY2Cex with $x$ between 5 and $7.5 \mathrm{~mol} \%$ (grain sizes were $1-2.5 \mu \mathrm{m}$ ). The SENB values observed in this investigation for YCe-TZP with grain sizes of $0.2-0.8 \mu \mathrm{m}$ are much lower than those of Duh and Wan. Evaluation of the toughness of YCe-TZP with grain sizes above 1-2 $\mu \mathrm{m}$ by e.g. the SENB or DCB technique is necessary to determine the extent of toughening if the $t$-phase becomes highly transformable under an applied stress field, i.e. with $M_{\mathrm{s}}$ temperatures just below room temperature.

Fig. 4 shows the variation of the fracture energy, $\gamma$ (calculated from $K_{\mathrm{Ic}}^{2} / E$, where $E$ is calculated from Equation 4 with $E_{0}=210 \mathrm{GPa}$ ) with grain size for ZY4Ce4 and ZY5. Grain sizes are in the range $0.18-0.76 \mu \mathrm{m}$. From this diagram it is clear that very little or no grain-size dependence of the fracture energy is observed in both TZPs. No irreversible transformation to the monoclinic phase took place during fracturing except for the largest grain size $(\sim 0.75 \mu \mathrm{m})$. The toughening mechanisms that are most probably operating in fine-grained TZPs will now be discussed.

The transformability of the t-phase under an applied stress increases with grain size [16]. Therefore, the extent of toughening (and hence the fracture energy) should scale with grain size in zirconia-toughened ceramics. Such an increase in fracture toughness has indeed been observed by Wang et al. [45] for 2.5Y-TZP upon increasing the grain size from $0.75 \mu \mathrm{m}$ to $1.3 \mu \mathrm{m}$. Irreversible $\mathrm{t} \rightarrow \mathrm{m}$ transformation was observed in their samples and the toughening increment was in good agreement with theoretical models based on a supercritical, irreversible, dilatational transformation $[46,47]$. In the fine-grained TZPs

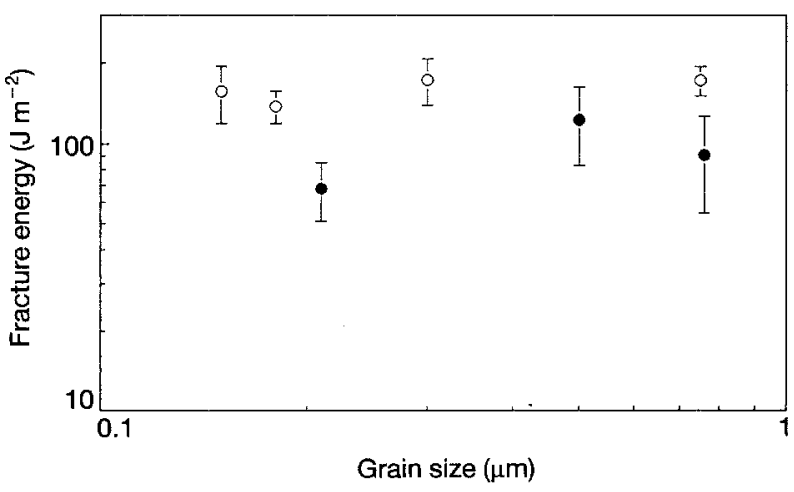

Figure 4 Variation of the fracture energy, $\gamma$, with grain size for (O) ZY4Ce4 and (O) ZY5. 
investigated here with grain sizes below $0.8 \mu \mathrm{m}$, very little or no irreversible transformation was observed on the fracture surfaces of SENB specimens. Still, these materials had a toughness in the range 7-9 $\mathrm{MPa} \mathrm{m}^{1 / 2}$ (for porosities $\leqslant 1 \%$ ).

Heuer et al. [48] recently summarized the available evidence from in situ observations for the stressinduced $\mathrm{t} \rightarrow \mathrm{m}$ transformation to occur reversibly under certain conditions. They concluded that to prevent the reverse transformation upon unloading, microcracking (or twinning) should occur in order to relieve the residual stresses associated with the forward transformation. Evans and Cannon [46] demonstrated that toughening can still occur in the case of a reversible transformation, provided that the reverse transformation takes place at a stress value which lies below that at which the forward transformation took place.

Part of the toughening observed in the fine-grained TZPs investigated here is possibly due to a stressinduced reversible $\mathrm{t} \rightarrow \mathrm{m}$ transformation. In situ observations are recessary to provide definite evidence for this hypothesis and to determine the critical grain size below which no reversible transformation during fracturing occurs. However, indirect evidence comes from the temperature dependence of the fracture toughness of ZY5 with $0.2 \mu \mathrm{m}$ grain size as measured by Theunissen et al. [23]. They observed a decrease of $K_{\mathrm{Ic}}$ from $7.3 \mathrm{MPa} \mathrm{m}^{1 / 2}$ at $20^{\circ} \mathrm{C}$ to $4.5 \mathrm{MPa} \mathrm{m}^{1 / 2}$ at $773{ }^{\circ} \mathrm{C}$. This can be explained by a decrease of the toughening contribution from a reversible $\mathrm{t} \rightarrow \mathrm{m}$ transformation caused by an enhanced stability of the t-phase with increasing temperature. At $775^{\circ} \mathrm{C}$, these authors also observed that the $K_{\mathrm{Ic}}$ of fine-grained ZY5 $(0.2-0.3 \mu \mathrm{m})$ was $4.5 \mathrm{MPa} \mathrm{m}^{1 / 2}$, while the toughness of coarser grained $(0.75 \mu \mathrm{m}) \mathrm{ZY} 5$ was $3 \mathrm{MPa} \mathrm{m}^{1 / 2}$. An additional toughening not related to reversible or irreversible transformation toughening is thus observed for fine grain sizes.

Tetragonal zirconia is a ferroelastic material and ferroelastic domain switching can be induced by an applied stress. This mechanism can contribute significantly to the toughness of non-transformable zirconia [49]. Ferroelastic domain switching leads to a preferred orientation of the $c$-axis orthogonal to the fracture surface and this can be easily recognized in a XRD pattern of the fracture surface [50]. The XRD pattern of the fracture surface of $Z Y 5$ with $0.18 \mu \mathrm{m}$ grain size showed that very little preferred orientation of the $c$-axis of the t-phase took place during fracturing. Consequently, the contribution of ferroelastic domain switching to the toughness of the materials investigated here can be neglected.

Crack deflection can be operating in the studied TZPs in a way similar to the deflection of cracks in tetragonal single crystals caused by their domain substructure. All investigated TZPs fractured intergranularly and crack deflection can occur at grain boundaries. This would lead to a high roughness of the fracture surfaces as has indeed been observed. Crack deflection is insensitive to temperature [51] and this might explain the enhanced high-temperature toughness of fine-grained Y-TZP compared to its coarser grained counterpart as mentioned above. A more elaborate discussion of crack deflection for finegrained TZP can be found elsewhere [23].

Recently, Krell and Blank [52] suggested that the macroscopic toughness of materials might be improved by increasing their grain-boundary toughness, $K_{\mathrm{lc}}^{\mathrm{gb}}$. According to these authors, the grain boundaries can be strengthened by the elimination of amorphous phases from the grain boundaries. The slightly higher toughness values observed here of the sinter forged TZPs compared to their free sintered equivalents (corrected for residual porosity) can be attributed to a strengthening of the grain boundaries, caused by the removal of the intergranular silicate film under the influence of the large compressive stresses applied during sinter forging.

In Section 3.1.3 it was established that the toughness of ZY4Ce4 (grain size $0.50 \mu \mathrm{m}$ ) increases from $7 \mathrm{MPam}^{1 / 2}$ to $8 \mathrm{MPam}^{1 / 2}$ after ageing in water at $185^{\circ} \mathrm{C}$ for $66 \mathrm{~h}$. During ageing, approximately $30 \%$ of the t-phase transformed at the external surface. The transformability of the t-phase is thus enhanced by this ageing treatment and this enhanced transformability will lead to an increase of toughening during fracturing by transformation toughening. A similar observation has been made by Kontouros et al. [30] on aged YTi-TZP.

\section{Conclusions}

1. The critical grain size, below which no lowtemperature degradation under hydrothermal conditions occurs, is smaller than $0.2 \mu \mathrm{m}$ for $2.6 \mathrm{~mol} \%$ $\mathrm{Y}_{2} \mathrm{O}_{3}$-stabilized TZP.

2. The stability of the t-phase in hot water $\left(185^{\circ} \mathrm{C}\right)$ for $2 \mathrm{~mol} \% \mathrm{Y}_{2} \mathrm{O}_{3}$-stabilized TZP can be strongly enhanced by alloying with ceria. The ceria content necessary to avoid degradation completely, depends on the grain size: at $0.2 \mu \mathrm{m} 4 \mathrm{~mol} \%$ ceria and at $0.6 \mu \mathrm{m} 6 \mathrm{~mol} \%$ ceria are required.

3. The SENB toughness of fully dense free sintered YCe-TZP is $7 \mathrm{MPa} \mathrm{m}^{1 / 2}$ for grain sizes of $0.2-0.8 \mu \mathrm{m}$. A fracture energy of $130 \mathrm{~J} \mathrm{~m}^{-2}$ has been calculated for this material. Very little or no irreversible transformation took place during fracturing.

4. The SENB toughness of very fine-grained $(0.16-0.25 \mu \mathrm{m}) \mathrm{Y}-\mathrm{TZP}$ and YCe-TZP, obtained by sinter forging at 1150 or $1200^{\circ} \mathrm{C}$, is $8-9 \mathrm{MPa} \mathrm{m}^{1 / 2}$. No monoclinic zirconia was detected on the fracture surface.

5. Reversible transformation toughening and crack deflection are possible candidates to explain the toughening of the very fine-grained TZPs examined here.

\section{Acknowledgements}

Akzo Chemicals bv is gratefully acknowledged for financial support of this investigation, Joop Snoeyenbos for machining and polishing and Arie Pleiter for his assistance with the hydrothermal ageing tests. Akzo Arnhem is acknowledged for offering the opportunity to do Raman measurements and Bas Peters 
is acknowledged for his assistance with these measurements.

\section{References}

1. K. TSUKUMA, Y. KUBOTA and T. TSUKIDATE, in "Advances in Ceramics", Vol. 12, "Science and Technology of Zirconia II", edited by N. Claussen, M. Rühle and A. Heuer (American Ceramic Society, Columbus, OH, 1984) p. 382.

2. J. WANG, W. M. RAINFORTH, I. WADSWORTH and R. STEVENS, J. Eur. Ceram. Soc. 10 (1992) 21.

3. T. SATO and M. SHIMADA, Am. Ceram. Soc. Bull. 64 (1985) 1382.

4. J. WANG, X. H. ZHENG and R. STEVENS, J. Mater. Sci. 27 (1992) 5348

5. M. M. R. BOUTZ, A. J. A. WINNUBST and A. J. BURGGRAAF, J. Eur. Ceram. Soc. 13 (1994) 89

6. M. M. R. BOUTZ, A. J. A. WINNUBST, A. J. BURGGRAAF, M. NAUER and C. CARRY, J.Am. Ceram. Soc., in press.

7. J. J. SWA B, J. Mater. Sci. 26 (1991) 6706

8. T. SATO and M. SHIMADA, ibid. 20 (1985) 3988

9. Idem, J.Am. Ceram. Soc. 68 (1985) 356.

10. T. SATO, S. OHTAKI, T. ENDO and M. SHIMADA, ibid. 68 (1985) C-320.

11. T. SATO, S. OHTAKI, T, ENDO and $M$. SHIMADA, in "High Tech Ceramics", edited by P. Vincenzini (Elsevier Science, Amsterdam, 1987) p. 281.

12. H. LU and S. CHEN, J. Am. Ceram. Soc. 70 (1987) 537.

13. A. J. A. WINNUBST and A. J. BURGGRAAF, in "Advances in Ceramics", Vol. 24A, "Science and Technology of Zirconia III", edited by S. Somiya, N. Yamamoto and H. Hanagida (American Ceramic Society, Westerville, OH, 1988) p. 39.

14. T. SATO, S. OHTAKI and M. SHIMADA, J. Mater. Sci. 20 (1985) 1466

15. M. WATANABE, S. IIO and I. FUKUURA, ibid. 19 (1984) 391.

16. D. J. GREEN, R. H. J. HANNINK and M. V. SWAIN, in "Transformation Toughening of Ceramics" (CRC Press, Boca Raton, FL, 1989) Ch. 3, p. 57.

17. T. SATO, S. OHTAKI, T. ENDO and M. SHIMADA, Int. $J$ High Technol. Ceram. 2 (1986) 167

18. M. T. HERNANDEZ, J. R. JURADO and P. DURAN, J. Am. Ceram. Soc, 74 (1991) 1254.

19. W. F. M. GROOT ZEVERT, A. J. A. WINNUBST, G. S. A. M. THEUNISSEN and A. J. BURGGRAAF, $J$ Mater. Sci. 25 (1990) 3449

20. R. R A J, J. Am. Ceram. Soc. 65 (1982) C-46.

21. H. TORAYA, M. YOSHIMURA and S. SOMIYA, ibid. 67 (1984) C-119.

22. A. W. PATER SON and R. STEVENS, Int. J. High Technol. Ceram. 2 (1986) 135.

23. G. S. A. M. THEUNISSEN, J. S. BOUMA, A. J. A. WINNUBST and A. J. BURGGRAAF, J. Mater. Sci. 27 (1992) 4429 .

24. K. TSUKUMA and M. SHIMADA, ibid. 20 (1985) 1178.

25. M. NAUER, Thesis 996, EPF Lausanne, Switzerland (1992) Ch. 2.

26. M. S. DADKHAH, D. B. MARSHALL, W. L. MORRIS and B. N. COX, J. Am. Ceram. Soc. 74 (1991) 584
27. K. VENKA TACHARI and R. RAJ, ibid. 65 (1987) 514.

28. F. F. LANGE, G. L. DUNLOP and B. I. DAVIS, ibid. 69 (1986) 237.

29. M. YOSHIMURA, Am. Ceram. Soc. Bull. 67 (1988) 1950

30. O. KRUSE, H. D. CARSTAN JEN, P. KONTOUROS, H. SCHUBERT and G. PETZOW, in "Science and Technology of Zirconia V', edited by S. P. S. Badwal, M. J. Bannistor and R. H. J. Hannink (Techomic Publ. Co., Lancaster, PA 1993) p. 163.

31. G. S. A. M. THEUNISSEN, A. J. A. WINNUBST and A. J. BURGGRAAF, J. Eur. Ceram. Soc. 9 (1992) 251.

32. S. SCH MAUDER and H. SCHUBER T, J, Am. Ceram. Soc. 69 (1986) 534.

33. H. SCHUBERT, ibid. 69 (1986) 270.

34. P. SCARDI, R. DI MAGGIO and L. LUTTEROTTI, ibid. 75 (1992) 2828

35. P. F. BECHER and M. V. SWAIN, ibid. 75 (1992) 493

36. M. M. R. BOUTZ, A. J. A. WINNUBST, A. J. BURGG.RAAF, M. NAUER and C. CARRY, J. Eur. Ceram. Soc. 13 (1994) 103.

37. M. L. MECARTNEY, J. Am. Ceram. Soc. 70 (1987) 54

38. A. E. HUGHES, F. T. CIACCHI and S. P. S. BADWAL, in "Science and Technology of Zirconia V", edited by S. P. S. Badwal, M. J. Bannistor and R. H. J. Hannink (Techomic Publ. Co., Lancaster, PA, 1993) p. 152.

39. G. S. A. M. THEUNISSEN, A. J. A. WINNUBST and A. J. BURGGRAAF, J. Mater. Sci. 27 (1992) 5057.

40. G. M. INGO, G. MATTOGNO, N. ZACCHETI P. SCARDI and R. DAL MASCHIO, J. Mater. Sci. Lett. 10 (1991) 320.

41. R. W. RICE, S. W. FREIMAN, R. C. POHANKA, J. J MECHOLSKY JR and C. C. WU, in "Fracture Mechanics of Ceramics", edited by R. C. Bradt, D. P. H. Hasselman and F. F. Lange (Plenum Press, New York, 1978) p. 849.

42. A. J. A. WINNUBST, K. KEIZER and A. J. BURGGRAAF, J. Mater. Sci. 18 (1983) 1958.

43. S. SAKAGUCHI, N. MURAYAMA, Y. KODAMA and F. WA K AI, J. Mater. Sci. Lett. 10 (1991) 282.

44. J. G. DUH and J. U. WAN, J. Mater. Sci. 27 (1992) 6197

45. J. WANG, M. RAINFORTH and R. STEVENS, Br. Ceram. Trans. J. 88 (1989) 1

46. A. G. EVANS and R. M. CANNON, Acta Metall. 34 (1986) 761.

47. R. McMEEKING and A. G. EVANS, J. Am. Ceram. Soc. 65 (1982) 242.

48. A. HEUER, M. RÜHLE and D. B. MARSHALL, ibid. 73 (1990) 1084.

49. R. A. CUTLER, J. R. REYNOLDS and A. JONES, ibid. 75 (1992) 2173.

50. A. V. VIRKAR and R. L. MATSUMOTO, in "Advances in Ceramics", Vol. 24, "Science and Technology of Zirconia III", edited by S. Somiya, N. Yamamoto and H. Hanagida (The American Ceramic Society, Columbus, $\mathrm{OH}, 1988)$ p. 653.

51. K. T. FABER and A. G. EVANS, Acta Metall. 31 (1983) 565.

52. A. KRELL and P. BLANK, J. Eur. Ceram. Soc. 9 (1992) 309.

Received 29 July 1993

and accepted 21 March 1994 